\title{
HUBUNGAN KEPATUHAN PROSEDUR TETAP PERAWATAN ULKUS DIABETIKUM DENGAN KEPUASAN PASIEN DIABETES MELITUS PENGGUNA BPJS PBI DI RSUD SLEMAN
}

\author{
Widuri, Dwi Agustina Sari, Akhmad Faisal \\ ${ }^{1,2,3}$ Program Studi S1 IImu Keperawatan STIKES Guna Bangsa Yogyakarta \\ e-mail: 1widuri@gunabangsa.ac.id, ${ }^{2}$ dwiagustianasari@gmail.com
}

\begin{abstract}
Background: Satisfaction is the degree of one's feelings after comparing the performance or results which felt with expectations. In this case the patient satisfaction as a benchmark the quality of Sleman hospital where the vision and mission is a quality health service delivery. Especially for compliance using SOP, the Sleman hospital is part of the process of achieving Satisfaction Patient Diabetes Mellitus User BPJS PBI at Sleman Hospital.
\end{abstract}

Objective:Knowing the relationship between compliance procedures care diabetic ulcers with satisfaction the patient diabetes mellitus user BPJS PBI at Sleman Hospital.

Methods:This research is research non experiment using the design descriptive correlative.This research was at Sleman Hospital, from May to July. With the methods samples being used were a total of sampling and the number of samples in this research is 26 of respondents.

Result:Of the 26 respondents there are as many as 23 nurses (88.5\%) carry out the action in accordance with procedures still make a high percentage of the level of satisfaction.

Conclusions:There is a correlation between compliance procedures care diabetic ulcers with satisfaction the patient diabetes mellitus user BPJS PBI at Sleman Hospital,with the result Asymp.Sig(2-sided)0,001<0,05.

Keyword: Procedures, Satisfaction, PBJS PBI

\section{PENDAHULUAN}

Berdasarkan Undang-Undang RI No. 44 tahun 2009 tentang Rumah Sakit, rumah sakit mempunyai tugas memberikan pelayanan kesehatan perorangan secara paripurna. Pelayanan kesehatan perorangan adalah setiap kegiatan pelayanan kesehatan yang diberikan oleh tenaga kesehatan untuk memelihara dan meningkatkan kesehatan, mencegah dan menyembuhkan penyakit, dan memulihkan kesehatan. Pelayanan kesehatan paripurna adalah pelayanan kesehatan yang meliputi promotif, preventif, kuratif, dan rehabilitatif. ${ }^{1}$
Dalam derajat kesehatan, masyarakat miskin yang masih sulit mendapatkan fasilitas dikarenakan sulitnya akses terhadap layanan kesehatan. Kesulitan akses pelayanan ini dipengaruhi oleh berbagai faktor seperti tidak ada kemampuan secara ekonomi dikarenakan biaya kesehatan yang mahal. Untuk menjamin akses penduduk miskin terhadap pelayanan kesehatan sebagaimana diamanatkan dalam Undangundang dasar 1945, sejak tahun 2005 telah diupayakan untuk mengatasi hambatan dan kendala tersebut melalui pelaksanaan kebijakan Program Jaminan Pemeliharaan Kesehatan Masyarakat Miskin. Program ini diselengarakan oleh Departemen 
Kesehatan melalui penugasan kepada PT Askes (persero) dalam pengelolaan program pemeliharaan kesehatan bagi masyarakat miskin. ${ }^{2}$

\section{Peserta Badan Penyelengara} Jaminan Sosial Penerima Bantuan luran (BPJSPBI) sebagai pelanggan yang menggunakan jasa layanan kesehatan di rumah sakit, membutuhkan layanan yang prima untuk proses penyembuhan penyakit yang dialaminya sekaligus mendatangkan rasa puas terhadap pelayanan kesehatan yang komrenhensif mencakup aspek promosi kesehatan, pencegahan, penyembuhan dan pemulihan bagi seluruh masyarakat yang seringkali menghadapi masalah menyangkut ketidakpuasan pasien terhadap mutu pelayanan. ${ }^{2}$

Penelitian dari Rizki tentang "Hubungan Mutu Pelayanan Kesehatan dengan Tingkat Kepuasan Pasien Jamkesmas di Instalasi Rawat Inap dr.Rasidin Kota Padang" didapatkan $82,7 \%$ responden menyatakan tingkat kehandalan petugas tidak baik, 80,2\% responden menganggap daya tanggap petugas tidak baik, $80,2 \%$ responden menyatakan jaminan petugas tidakbaik, $79 \%$ responden menyatakan empati petugas tidak baik, 85,2\% responden menyatakan bukti fisik tidak baik. ${ }^{2}$

Salah satu komplikasi penyakit diabetes melitus yang sering dijumpai adalah ulkus diabetik, yang dapat bermanifestasikan sebagai ulkus,infeksi dan gangren danartropati Charcot. Sekitar $15 \%$ penderita diabetes melitus (DM) dalam perjalanan penyakitnya akan mengalami komplikasi ulkus diabetika terutama ulkus di kaki. Sekitar 14-24\% di antara penderita kaki diabetika tersebut memerlukan tindakan amputasi. ${ }^{3}$

Hasil studi pendahuluan yang telah dilakukan di RSUD Sleman dalam rentang waktu 1 Januari 2014 sampai 10 Maret 2014 ditemukan jumlah pasien Ulkus Diabetes Melitus BPJS PBI sebanyak 30 orang dari 3 bangsal. Pengambilan data tersebut berasal dari buku register pasien. Ulkus merupakan penyakit yang sedikit diderita pasien pada waktu itu, sehingga perawatan yang dilakukan kurang optimal. Melalui hasil wawancara juga ternyata masih didapatkan beberapa keluhan pasien rawat inap BPJS PBI yang berkaitan dengan pelayanan keperawatan perawatan Ulkus Diabetes Melitus antara lain : Merupakan rumah sakit atau tempat pertama masyarakat Sleman berobat khususnya penyakit Diabetes Melitus, pasien merasa masih ada perawat yang bersikap kurang ramah, dalam tindakan perawatan ulkus DM dan masih banyak pasien yang merasa kurang dilayani dengan baik dan kebersihan alat. Berdasarkan latarbelakang masalah, maka penulis tertarik untuk meneliti "Hubungan Kepatuhan Prosedur Tetap Perawatan Ulkus Diabetikum Dengan Kepuasan Pasien Diabetes Melitus Pengguna BPJS PBI di RSUD Sleman".

\section{TUJUAN PENELITIAN}

Mengetahui hubungan antara Kepatuhan Prosedur Tetap Perawatan Ulkus Diabetikum Dengan Kepuasan Pasien Diabetes Melitus Pengguna BPJS PBI di RSUD Sleman.

\section{METODOLOGI PENELITIAN}

Penelitian ini merupakan penelitian lapangan yang dilakukan dengan menggunakan rancangan deskriptif korelatif. Lokasi penelitian bertempat di Rumah Sakit Umum Daerah Sleman, yang dilaksanakan mulai bulan Mei sampai bulan Juni tahun 2014.

Populasi yang diambil dalam penelitian ini adalah pasien Ulkus Diabetikum pengguna BPJS PBI yang dirawat diruang rawat inap RSUD. Metode sampel yang digunakan adalah Total Sampling, dengan jumlah sampel 30 orang. 
HASIL DAN PEMBAHASAN

\section{Karakteristik Responden}

Tabel 1. Distribusi Karakteristik Responden Ulkus Diabetikum Pengguna BPJS PBI RSUD Sleman 2014

\begin{tabular}{llll}
\hline \multicolumn{2}{l}{ Karakteristik } & Frekuensi & $\%$ \\
\hline Jenis & Laki-laki & 22 & 84,62 \\
Kelamin & Perempuan & 4 & 15,38 \\
Usia & 26-35Tahun & 1 & 3,85 \\
& 46-55Tahun & 6 & 23,08 \\
& 56-65Tahun & 15 & 57,69 \\
& $>$ 65Tahun & 4 & 15,38 \\
Total & & $\mathbf{2 6}$ & $\mathbf{1 0 0}$ \\
\hline
\end{tabular}

Dari tabel 1 diatas dapat diketahui bahwa sebanyak 26 responden Ulkus Diabetikum pengguna BPJS PBI di RSUD Sleman terbanyak berjenis kelamin lakilaki 22 orang $(84,62 \%)$ danberusia 56 65 tahun sebanyak 15 orang $(57,69 \%)$.

2. Analisa Univariat
a. Kepatuhan
Prosedur Tetap
PerawatanUlkus Diabetikum

Tabel 2. Kepatuhan Prosedur Tetap PerawatanUlkus Diabetikum

\begin{tabular}{lll}
\hline Kategori & Frekuensi & $\%$ \\
\hline Patuh & 23 & 88,5 \\
Tidak & 3 & 11,5 \\
Patuh & & \\
Total & $\mathbf{2 6}$ & $\mathbf{1 0 0}$ \\
\hline
\end{tabular}

Berdasarkan tabel 2 diketahui bahwa tingkat kepatuhan menggunakan prosedur tetap sesuai standar RSUD Sleman mempunyai presentasi bagian yang paling besar, yaitu $88,5 \%$ (23 kali tindakan).

Hasil ini sejalan dengan penelitian yang dilakukan oleh Himatusujana (2008) tentang "Hubungan Tingkat Kepatuhan Pelaksanaan Protap Perawatan Luka Dengan Kejadian Infeksi Luka Post Sectio Caesarea (SC) Di Ruang Mawar I RSUD Dr. Moewardi Surakarta" dengan hasil $60,5 \%$ patuh, 18,6\%kurang patuh, dan $20,9 \%$ tidak patuh. ${ }^{4}$

Selaras dengan teori yang dikemukakan oleh Smet, kepatuhan adalah tingkat seseorang melaksanakan suatu cara atau berperilaku sesuai dengan apa yang disarankan atau dibebankan kepadanya. Dalam hal ini kepatuhan pelaksanaan prosedur tetap (protap)adalah untuk selalu memenuhipetunjuk atau peraturan-peraturan dan memahami etika keperawatan di tempat perawat tersebut bekerja. Kepatuhan merupakan modal dasar seseorang berperilaku. ${ }^{5}$

b. Kepuasaan Pasien Diabetes Melitus Pengguna BPJS PBI di RSUD Sleman

Tabel 3. Kepuasaan Pasien Diabetes Melitus Pengguna BPJS PBI di RSUD Sleman

\begin{tabular}{lcl}
\hline Kategori & Frekuensi & $\%$ \\
\hline Puas & 23 & 88,5 \\
Tidak & 3 & 11,5 \\
Puas & & \\
Total & 26 & 100 \\
\hline
\end{tabular}

Berdasarkan tabel 3 diketahui bahwa kepuasaan pasien Ulkus Diabetikum pengguna BPJS PBI di RSUD Sleman sebagian besar dengan presentase $88,5 \%$.

Hasil penelitian ini juga sejalan dengan thesis Anjaryani, W.D (2009), tentang "Kepuasan Pasien Rawat Inap Terhadap Pelayanan Perawat di RSUD Tugurejo Semarang" yang menyebutkan bahwa lebih dari separuh responden $(53,3 \%)$ merasa puas terhadap pelayanan pasien, walaupun masih terdapat yang belum puas dengan pelayanan pasien. Kepuasan pasienmerupakan salah satu hal sangat penting dalam meninjau mutu pelayanan khususnya pelayanan keperawatan suatu rumah sakit. Suryawati (2004) mendefenisikan kepuasan pasien 
dari sisi yang berbeda, pasien memasuki rumah sakit dengan serangkaian harapan dan keinginan. ${ }^{6}$

\section{Analisa Bivariat}

Tabel 4. Hubungan Kepatuhan Prosedur Tetap Perawatan Ulkus Diabetikum Dengan Kepuasan Pasien Diabetes Melitus Pengguna BPJS PBI di RSUD Sleman

\begin{tabular}{llll}
\hline & Value & df & Asymp.Sig. \\
\hline $\begin{array}{l}\text { Person } \\
\text { Chi- } \\
\text { Square }\end{array}$ & 10.097 & 1 & .001 \\
\hline
\end{tabular}

Berdasarkan hasil tabel 4 diatasdapat dijelaskan bahwa, terdapat hubungan yang signifikan antara kepatuhan prosedur tetap perawatan ulkus diabetikum dengan kepuasan pasien Diabetes Melitus pengguna BPJS PBI di RSUD Sleman, ditunjukkan dengan hasil analisa Person Chi- Square $p$ value 0,001 $(<0,05)$.

Hal tersebut didukung oleh penelitian Suharti (2005) dengan judul "Hubungan mutu pelayanan Keperawatan Dengan Kepuasan pasien di Ruang Rawat Inap RSUD Kota Yogyakarta", menunjukkan hasil mutu pelayanan keperawatan relative bermutu, responden relative puas pula terhadap pelayanan keperawatan. ${ }^{7}$

Penelitian ini juga selaras dengan penelitian Dahlan (2006), tentang 'Hubungan Mutu Pelayanan dengan Tingkat kepuasan Pasien Non Askes di Instalasi Rawat Jalan Rumah Sakit Achmad Mochtar Bukit tinggi," dengan jumlah sampel 404 responden, hasilnya adalah ada hubungan yang positif antara mutu layanan dengan kepuasan pasien. ${ }^{8}$

Semakin tinggi kualitas layanan yang diberikan semakin meningkat pula kepuasan pasien. Sebagaimana juga dalam teori Budiastuti bahwa kepuasan dapat diartikan sebagai perasaan puas, rasa senang dan kelegaan seseorang dikarenakan mengkonsumsi suatu produk atau jasa untuk mendapatkan pelayanan suatu jasa. Jadi, kepuasan atau ketidakpuasan adalah kesimpulan dari interaksi antara harapan dan pengalaman sesudah memakai jasa atau pelayanan yang diberikan. ${ }^{9}$

\section{KESIMPULAN DAN SARAN}

Berdasarkan hasil analisis data dan pembahasan, maka kesimpulan dalam penelitian ini dapat dirumuskan sebagai berikut:

1. Kepatuhan prosedur tetap perawatan Ulkus Diabetikum RSUD Sleman yang paling tinggi adalah kategori patuh $(88,5 \%)$.

2. Kepuasan pasien Diabetes Melitus pengguna BPJS PBI di RSUD Sleman yang paling tinggi adalah kategori puas $(88,5 \%)$.

3. Ada hubungan antara kepatuhan prosedur tetap perawatan ulkus diabetikum dengan kepuasan pasien Diabetes Melitus Pengguna BPJS PBI di RSUD Sleman. Dengan hasil Asymp.Sig (2-sided) 0,001<0,05.

Saran untuk Rumah Sakit Umum Daerah Sleman dapat dijadikan kontribusi, pertimbangan bagi peningkatan kualitas pelayanan keperawatan, dapat dijadikan masukan terhadap pelaksanaan kualitas RSUD Sleman sesuai prosedur tetap, terutama dalam memberikan perawatan Ulkus Diabetikum diwaktu yang mendatang dan memberikan masukan untuk memperbaharui protap yang up date.

\section{DAFTAR PUSTAKA}

1. Depkes RI. 2009. UU No. 44 Tahun 2009 tentang Rumah Sakit.

2. Ari, Andi Rizki. 2011. Hubungan Mutu Pelayanan Kesehatan Dengan Tingkat Kepuasan pasien Jamkesmas Di Instalasi Rawat Inap RSUD dr.Rasidin Kota Padang.Skripsi.

3. Muchlisin. 2012. Perawatan Kaki Diabetik, dalam Penatalaksanaan Diabetes Melitus Terpadu. Jakarta, FKUI.

4. Himatusujana. 2008. Hubungan Tingkat Kepatuhan Pelaksanaan 
Protap Perawatan Luka Dengan Kejadian Infeksi Luka Post Sectio Caesarea (SC) Di Ruang Mawar RSUD Dr. Moewardi. Surakarta. Skripsi

5. Smet. 1994. Teori Kepatuhan, diakses di www.perilaku.com tanggal 12/06/2014.

6. Anjaryani, Wike Diah. 2009. Kepuasan Pasien Rawat Inap Terhadap Pelayanan Perawat di RSUD Tugurejo Semarang. Skripsi.

7. Suharti. 2005. Hubungan mutu pelayanan Keperawatan Dengan Kepuasan pasien di Ruang Rawat Inap RSUD Kota Yogyakarta. Skripsi.

8. Dahlan. 2006. Hubungan Mutu Pelayanan dengan Tingkat kepuasan Pasien Non Askes di Instalasi Rawat Jalan Rumah Sakit Achmad Mochtar Bukit Tinggi. Skripsi.

9. Budiastuti. 2002. Kepuasan Terhadap Jasa Pelayanan. Diakses di www.proseskeperawatan.com tanggal 08/02/2014 